\title{
Mission as Oikumenical Doxology - Secularized Europe and the Quest for a New Paradigm of Mission. Empirical Data and Missiological Reflections
}

\section{Henning Wrogemann ${ }^{1}$}

\begin{abstract}
For more than a century now, Christianity's influence within many European countries has been in decline. Since especially the 1960s, there has been a corresponding and massive loss of church members. Despite the development of new forms of missionary engagement, the trend has not stopped, and it is very likely to continue for some time. What reasons lie behind it? How should the church address the challenges presented by this situation? These questions cannot, of course, be dealt with in detail in a single article. After the survey of statistical data and the range of its sociological interpretations, I will focus, third, on the missionary efforts conducted by the churches in Great Britain and Germany. Finally, I propose a specific missiology termed "oikumenical doxology" which I consider applicable to the situation in Germany, in particular, and European countries, in general.
\end{abstract}

Keywords: Oikomene, doxology, Secularization, Europe

\section{European Religious Landscape in the 21st Century - Some statistical data}

In the year 1900, almost every European societies was 98\% Christian. These figures dropped during the 20th century and especially so since the 1960s. By 2006, the percentage of church members in some countries dropped by a range of $10-20 \%$, including Ireland with $88,6 \%$, Portugal $87 \%$, Denmark $88 \%$, the western region of Germany $83,4 \%$, Poland $95,5 \%$. Other countries witnessed a more serious rate of decline. France had a church membership of roughly 51\%, the Netherlands 52,6\%, the Czech Republic 30,6\% Hungary 53\%, Estonia $33,9 \%$ and the eastern regions of Germany had 22,7\%. (Pollack / Müller 2011; Pickel / Müller 2009) In short, the statistical data records a 10 to $50 \%$ decline in church membership across Europe.

During this same period, most of these societies became more pluralistic in terms of religious adherence. In lots of western European countries, due to immigration, the percentage of the Muslim population increased to between 5 to $10 \%$ of the population. One also finds a wide range of generally available recourses exploring alternate religious forms: Zen-meditation, esoteric books, journals, workshops, seminars, retreats and the like. One can thus identify three

1 Dr. theol. Habil. Henning Wrogemann holds the chair for Missiology, Science of Religion and Ecumenics at the Protestant University Wuppertal, Germany. His email address is: henning.wrogemann@kiho-wuppertal-bethel.de 
forms of pluralism: a pluralism of religious traditions (i.e., Christians, Muslims, Buddhists), a pluralism of Christian presence in terms of different denominational and cultural traditions, and a pluralism of religious practices (i.e. esoteric "market"). The decline of church membership, on the one hand, and the rise of religious pluralism, on the other, prompts the missiological question of how to cope with this situation.

\section{Secularization, Market-model, Individualization - sociological interpretations}

Sociologists of religion have, for decades, discussed the phenomenon of religious decline in western societies. During the 1960s and 70s, lots of sociologists expected every society in the world to follow the patterns of modernization in the West. Religious affiliation would decline worldwide and religions in general would lose social influence. According to the theory of secularization, the modernization of societies leads to industrialization, the differentiation of the society into a variety of sub-systems and a rationalization of life in general. Religions would lose control of most parts of social life because jurisprudence, the economy, politics and science no longer require a religious basis. Religion, as a consequence, becomes one sub-system alongside many others. Religion loses the ability to direct knowledge and education, and ceases to be a source of "help"; insurance-systems and solutions based on scientific research render religion ever more obsolete. Lots of sociologists expected religions to decrease in membership to the point, perhaps, of vanishing from human society. (Gabriel / Pollack 2012; Pickel 2009a)

Secularization, furthermore, is a process that takes place on different levels. At the institutional level it means a decline of formal membership or religious adherence (even though it is hard to define what "membership" and "adherence" means, since different religious traditions have different requirements for belonging.) In the Christian tradition, church membership indicates belonging. At the level of religious behavior, participation serves as indicator: how often does one take part in religious ceremonies like Sunday services, baptism, marriage, burial, Christmas Eve, Easter celebrations and the like. At the level of personal experience it becomes a question of the nature and form of religious experiences, or of whether a person believes in whatever transcendent reality, or of whether a person regards religious ideas, values or experiences as important for her or his life.

Missiological reflection, therefore, could analyze the behavior of a certain local population and would be challenged to find appropriate forms of religious activities, religious teaching and forms of belonging.

A different approach became dominant during the 1980s and 90s. The market model, as developed by US-American sociologists like Peter L. Berger (Berger 1963), Rodney Stark and Roger Finke (Finke / Stark 2005), 
regard human beings as innately interested in religion. Building on this premise, the question became one of whether religious groups were able to satisfy the religious needs of the people. Europe's secularization was seen as consequent on the centuries long monopoly of a single state religion. With this privileged status, these religious institutions lost their ability to fit to the needs of the people. From the very beginnings of the USA, by contrast, religious belonging resulted from competition in a free religious market. Competition leads to a vibrant atmosphere of trial and error through the attempt to gather and to retain large numbers of adherents. Religious vitality, therefore, is an outcome of religious competition. After the end of the tradition of state religion in many European countries and especially after the collapse of communism in Eastern Europe, theorists of the market model expected a new wave of religious interest, competition and a renaissance of religious life in Europe. (Stark / Iannacone 1994)

Missiological reflection would, therefore, expect to bring about a Christian revival by introducing a wide range of different denominations and new attempts at planting churches. In contrast to the model of secularization, the market model in no way regards religion and modernity as incompatible. It seems, rather, to be a question of demand and supply. The demand-side is seen as rather stable, whereas the supply-side underwent significant change. (Stark / Finke 2002). Should a stricter separation of state and religion be welcomed, as this would stimulate more competition resulting in a revivalization of churches, congregations and religious life in general?

Before entering this discussion, let us briefly summarize a third approach: the model of individualization. (Pollack/ Pickel 2007; Pickel 2009) The modernization of societies, according to this theory, does not necessarily indicate the degradation of religious life. On this point, the market model and that of individualization agree with each other. They differ, however, with regard to social forms: the model of individualization expects the decline of religious institutions because of the lessening relevance of communal forms of religious life. Today individuals seek to answer their questions and to satisfy their religious demands mostly by themselves. Individualization means that, while religious demand might remain stable, the social forms of religious life change. New forms, like workshops or seminars, might become more attractive to people because these require no formal, long lasting membership. These open forms (i.e. workshops, seminars) seem to be more appropriate for contemporary religious experience.

Missiological reflection, therefore, would need to focus on new forms of Christian presence which might better correspond to the demands of people exploring their own paths of religious experience. The challenge is to find open forms of Christian practice, ones different from ordinary congregations, which nonetheless preserve Christian doctrines and ethics. What would new forms of Christian presence - like Christian networking - look like? Is it possible to give up the idea of a "congregation of believers"? 


\section{Mission to Europe with regard to Great Britain and Germany - a comparison}

Of these three theoretical approaches, does one explain better the religious changes within Europe than the others? Is there a definite tendency of decline (secularization model)? Is there a revival after the collapse of communism (market model)? Are people less interested in institutionalized religion, but still interested in new forms of religious experience (the model of individualization)? While the empirical findings resist the application of general statements, some important observations can be made. Within the British context, the Anglican Church declared 1990 to 2000 to be the "decade of evangelization." Conferences on church planting had taken place through the 1980s. A 2004 study found that $40 \%$ of the British population to be unchurched, $40 \%$ dechurched, while only $20 \%$ of the population took part in church life to some degree. The Anglican Church promotes the Alpha Course as a means to witness to the gospel. Between 1990 and 2005, roughly 1,8 Million people took part in this course. Despite these efforts, the situation remains challenging. In 1970 , about $14 \%$ of British children took part in Sunday schools, but by 2000 this number had dropped to $4 \%$.

Because many areas, including suburbs, have no church life there is a great concern for church planting. As the challenge is to re-discover Christian forms of social networking, so the term "church planting" covers a wide variety of Christian presence. (Hopkins 1991) There is no general strategy; the hope is that unexpected forms of Christian life will develop. In 2004, the Church of England released a text entitled Mission Shaped Church. The main idea is that an existing congregation tries to revive a "dead" congregation or reopen a closed congregation by sending groups of devoted Christians to this other place to establish a Christian presence. The inculturation and deculturation of the Christian presence is viewed as an ongoing process. Only through the new and emergent forms of Christian life can the demands of the local people be met. Even though lots of new congregations have been founded since the 1980s these encouraging signs of revival are not yet strong enough to stop the general tendency of membership decline. Nevertheless, a new mission spirit has revived not only particular Christian groups, but also the church as a whole as it supports these efforts of missionary engagement.

The situation in Germany differs a great deal from that of Britain due to a number of reasons that cannot be treated at length in this paper. First of all, church membership in the western part of Germany has proven to be rather stable. $83 \%$ of the population retains membership in either the Roman-Catholic or Protestant mainline churches. This percentage, however, continues to decline at a rate of about $1 \%$ per year. One also needs to 
account for the significant differences between the churches within bigger cities like Hamburg, Berlin or Frankfurt (Main), on the one hand, and rural areas, on the other. To give one example, in the city of Hamburg, the church membership recently dropped below $50 \%$, while 30 kilometers south of Hamburg church membership remains at over $80 \%$. Following the theory of secularization, these figures are remarkable: because modernization effects the whole of society, church membership should drop everywhere to the same degree. On the other hand, following the market theory one could expect religious life to become vitalized, since with the increase of a Muslim population and the entrance of other forms of religious beliefs and practices would stimulate a certain kind of competition. But, according to empirical research, this is not the case.

Empirical data both from West and East Germany clearly show that people without religious ties do not have the desire to deal with religious issues. About $30 \%$ of the total German population, that is, about $15 \%$ in the western parts and $70 \%$ in the eastern parts do not have any religious affiliation. In the eastern parts of Germany it is common not to belong to any religious group. Common sense dictates that it is simply normal not to be religious. In the western parts it is still common to belong to a church. The common sense in the eastern parts of Germany does not support religious life at all; belonging to the church is not normal. Within the group of people without any religious affiliation, the majority is - according to social research - neither interested in religious matters nor interested in a broader variety of religious supplies. Therefore, the theory of individualization proves not to be true for the German context: People do not leave the churches through a longing for alternative religious practices. The opposite is true: people who express interest in other religious activities like meditation are mainly still members of the churches.

The empirical findings of German researches contradict also the market model approach: the majority of people who have never been, or who are no longer, church members do not want a broader range of religious groups, activities and supplies. There is - at least for the German context - no evidence that a greater of religious pluralism revitalizes of religious life. One main reason for the stability of church membership and support in the western parts of Germany is the good cooperation between the state and the churches. The common sense regards churches as an integral and important part of the German social system. Besides the state, Christian diaconic organizations are Germany's second largest employer with about 1, 5 million people working in hospitals, kindergartens, social services, counceling, medical services and the like. Churches have a generally good reputation, even though scandals occur from time to time. Protestant churches lose about 120.000 members per year, while about 60.000 persons per year become new members of the churches. The reasons 
behind membership are manifold, and are very often a matter of tradition, special circumstances, the willingness to marry, or to let the children be baptized. Conversion is a less important factor. German churches seek to stabilize their membership through a variety of activities. In the western parts of Germany, mainline churches remain "the" official religion. In the eastern parts, however, the common sense regards churches as institutions closed to the ruling elite. As a result, lots of people regard the institutional aspect of the churches with suspicion.

What kind of mission theology is needed with regard to these contexts? I opt for a new approach, one which understands mission as oikumenical doxology. This understanding fits especially to the German situation, but it shares some aspects that are relevant in other contexts as well. It is my conviction that mission theology in a globalized world needs to be open to other contexts since Christians are called to witness as brothers and sisters both in a local environment and under an intercultural horizon. It is the intercultural connections that, on the one hand, help to encourage local Christian communities and, on the other hand, make it possible to see one's own context with new eyes.

\section{Mission as Oikumenical Doxology - A New Paradigm of Mission}

Many of issues, relevant in other societies, do not feature within western societies. Neither reconciliation nor poverty has proved of major interest, nor have topics like healing, deliverance or spiritual warfare. The highly secularized societies of the West have to deal with the privatization of life, with consumer societies and different types of lifestyle within one and the same society. Societies have become segregated according to different tastes, ages, professions, and lifestyles. Mainline churches as the "official religion" must address as many milieus and lifestyles as possible. But this proves to be difficult since it is almost impossible to bring together people from different milieus in one and the same Sunday service. As the churches try to retain as many people as possible - according to observations made already by Ernst Troeltsch and Max Weber - so the churches have to embrace folk religion. In other words, the more the churches emphasize Christian doctrines and focus on "real Christian life," the more people they are likely to lose, because neither church members nor other people like to be told what to believe and what is right and wrong. Missionary activities, therefore, have to be sensitive, on the one hand, but they have to offer new approaches to Christian faith and practice, on the other.

Within the churches many workers suffer from a burnout syndrome. The financial resources are constantly shrinking although the responsibilities have either remained the same (Sunday services, confirmation classes, burials, 
baptisms, counseling, youth work, Bible groups, Christian ethics and politics, public relations, administration and others), or have increased due to the decreasing number of supported ministers. In my opinion these challenges can only be dealt with if Christians focus anew on the testimony of the Bible. It is noteworthy that the new Testament regards mission not only as a sending of people, but also as an expanding of atmospheres, that is, the expansion of the splendor of God, the power of God and the Glory of God. In the following I will focus primarily on 2. Corinthians and the Gospel of John, where the theme of glorification is of great importance. (Blum 2008; Harrison 2010; Nielsen 2010)

\section{Mission as Glorification of God}

Whereas missiologists like Bevans and Schroeder posit "prophet dialogue" as the relevant mission theology for today (Bevans / Schroeder 2004), this seems to be rather irrelevant for the German context, and, I assume, for the contexts of many other countries in Western Europe. In my opinion, mission has to be understood as a doxological endeavor. My thesis is this: Christian mission is grounded in the glorification of the triune God and mission aims at opening up human beings who have experienced help, liberation and reconciliation to glorify God, be it in the name of Jesus Christ or for the help people have received from Christian witnesses. The goal of life is to become transparent to its meaning: to take part in the glorification of God through praise and action. (Wrogemann 2012) Christian communities witness to God's glory by resonating the power of God. The goal of mission, therefore, is not primarily the founding of churches, not witness through social action, not numerical growth or missionary presence, nor it is an encounter with power. The goal is to let people become part of the glorification of God. One key text is 2. Cor. 3, 17-18: "Now the Lord is the Spirit, and where the Spirit of the Lord is, there is freedom. And all of us, with unveiled faces, seeing the glory of the Lord as though reflected in a mirror, are being transformed into the same image from one degree of glory to another; for this comes from the Lord, the Spirit." Since this process of glorification is transforming the world, it is a missionary process. Since more and more people get involved in this process of transformation, God's redeeming and liberating power in the name of Jesus Christ opens up more and more people to thank God for whatever relief they have experienced.

This is expressed clearly in 2. Cor. 4, 15: "Yes, everything is for your sake, so that grace, as it extends more and more people, may increase thanksgiving, to the glory of God." The activities of Paul and his companions in mission are directed to the Christians in Corinth, grounded in the experience of God's overflowing grace, prompting the thanksgiving of Christians and others, and praising God for the help they have been granted. But it is important to note that this increase of thanksgiving attracts other 
people to listen to the word of God, to seek contact with Christian witnesses and to join the Christian communities, as shown in 2. Cor. 9, 10-13:

"He who supplies seed to the sower and bread for food will supply and multiply your seed for sowing and increase the harvest of your righteousness. You will be enriched in every way for your great generosity, which will produce thanksgiving to God through us; for the rendering of this ministry not only supplies the needs of the saints but also overflows with many thanksgivings to God. Through the testing of this ministry you glorify God by your obedience to the confession of the gospel of Christ and by the generosity of your sharing with them and with all others."

The thanksgiving of the community is a powerful force of mission, even though it is not intentionally meant as a missionary activity, but results rather from the experience of relief. Once again: a doxological understanding of mission grounds mission in the glorification of God, because Jesus Christ himself glorifies God in his life, his word and deeds, his action, his suffering, his obedience and his death. One the other hand, Jesus Christ is himself glorified by God the Father in raising him from the dead, in sending the Spirit on the disciples, which is the Spirit of Christ, and sending the disciples into the world.

\section{Mission and power - Witnessing within the context of decline}

Thinking about mission within European contexts has to begin with the question: where does the power of mission come from? In many German churches, for instance, mission is regarded as a task in addition to the manifold requirements that pastors, deacons and others have to fulfill. Some ask whether mission is still possible or even permitted in a society mainly indifferent to the Christian message. What is necessary is a new understanding of Christian identity as a missionary identity, not in terms of more activities to be conducted, but in terms of spiritual life. Paul states, "this extraordinary power belongs to God and does not come from us." But this means that, though this power is directed to us, it rests on God and our receptiveness. Or, the power of God is only experienced when Christians take time to devote themselves to the glorification of God. To give an example: many full-time workers in German congregations are so busy fulfilling different tasks that they do not find enough time to read the Bible, to pray and to rest. A spiritual crisis soon accompanies the physical burnout.

According to Paul, God gives an overflow of his grace and this results in the promise of joy and power: "May the God of hope fill you with all joy and peace in believing, so that you may abound in hope by the power of the Holy Spirit." (Rm. 15, 13) Mission as oikumenical doxology emphasizes 
the need to understand Christian identity: even though church membership is in decline, even though church buildings need to be sold, even though the significant efforts of Christian witnesses receive little response in terms of numbers, it is the core of Christian identity to glorify God and to take part in God's history with humankind.

\section{Mission and experience - Witnessing in society of many choices}

In European societies, people are free to choose their kind of lifestyle, and this proves to be true also in religious matters. The fact of a religious tradition no longer guarantees that people will remain a member of a church. People very often choose religious belonging according to the experiences they have had. For Christian churches, it is necessary to provide social spaces where people can experience Christian life. These spaces need an inviting atmosphere; they need expressions of Christian spiritual and social life that attract people. Mission in doxological perspective takes into account that glorification has something to do with human senses, such as seeing the splendor of God in the face of Jesus Christ, who "is the reflection of God's glory and the exact imprint of God's very being" (Hebr. 1, 3), like smelling the "fragrance that comes from knowing" Christ (2. Cor. 2, 14), like tasting the "spiritual milk, so that by it you may grow into salvation - if indeed you have tasted that the Lord is good." (1. Peter 2, 2-3). Anglican missionary practices have shown that believing comes after belonging, and that behaving comes after believing. In a German context, the question is how ordinary congregations, with an average membership role of 2000-5000 members, but with an average church attendance of about $2-5 \%$, can create social spaces inviting to non-members.

Statistical data reinforces the anecdotal evidence that lots of people actually do not want to be approached by religious activists. So how might the church create spaces of encounter with people who are mainly indifferent to questions of religious belief and practices? In my opinion, the convincing political, ethical and social engagement of congregations and churches serves to maintain a good reputation of Christian churches within the broader society. These activities will help to maintain a common sense that makes it unlikely that even more people will leave the churches. This common sense should, equally, make it easier for people to become church members since the church is commonly accepted as a helpful institution. But this alone is not enough since every congregation needs social networks that form the center of the congregation. If there are no gatherings of people where the taste, the smell and the beauty of the gospel can be experienced, the congregation will die out in the long run. Therefore, new forms have to be developed within the given setting. Personal contact in a welcoming social environment is crucial. Based on research on conversion in Germany, 
$76 \%$ of new Christians said that their decision to convert was due to their relation to Christian friends. Missionary activities, therefore, should focus on Christian networking, and on developing intercultural and interreligious networking. Christian communities are called to live together with other people, foreigners and strangers.

\section{Mission and cultural diversity - Witnessing in pluralistic society}

Mission as oikumenical doxology stresses the fact that the triune God wants to be glorified among a broad variety of tongues, peoples and cultures, since he himself is the ultimate source of all creativity. A multitude of praise corresponds to the vividness of God as the creator and sustainer, redeemer and sanctifier. (Wrogemann 2012a) The question in a pluralistic and multicultural society becomes one of whether different Christian groups are willing and able to accept other forms of worship, other emphases in terms of ethics, and other doctrinal teachings. Mission theology itself needs to argue for cultural diversity within Christian churches and congregations. In Germany, ordinary congregations often suffer from a certain kind of narrowness regarding access to different milieus. Networking very often takes place only among people of one and the same social strata, mainly among people of the middle class. The challenge is to extend this networking to other social strata (such as the youth sub-culture, i.e., hip-hop scene, gothic scene and others), milieus and professions. But who is able to take up this initiative? To open up a Hip-Hop-Christian network would require somebody who is already member of the Hip-Hop scene. So, how is the extension of Christian networking possible? This kind of mission is not viable through the application of different techniques, but only through the kenotic character of a congregation which gives space for this kind of activities. Whether a new kind of networking will occur is not something which can be managed. It is possible, however, to influence existing Christian congregations so that they do not regard different cultural forms of Christian life as a threat, but welcomes them as new expressions of the creativity of the Spirit of God. Once again, this example shows that mission in European contexts is mainly a spiritual matter.

\section{Mission and the name of Christ - Witnessing in a media society}

One can characterize European, like many other societies worldwide, as media societies: in the information market many of competitors struggle to attract as many customers as possible. This requires memorable images that are easily distinguished from others, images that are interesting and appealing, images that symbolize the content of an offer. Likewise in the market of religious ideas and 
practices, lots of agents compete with each other. In this setting, it is necessary to focus on the core message of the Christian tradition, that is, on the name of Jesus Christ as the summary of the final and ultimate activity of God to reconcile the world with himself. The story of Jesus, his life, actions, suffering, death and resurrection are summarized in this name. But how to communicate this name in a social environment where people, in the main, do not want to be confronted with religious truth claims? A doxological understanding of mission presents this need to witness to the name of Christ in a new way. The leading idea is that names are social entities. That is: names are expressions of individual and social experiences. If a loving one hears the name of the beloved, his or her heart beats faster. If someone has a good reputation - a good name this means that long lasting experiences with this person demonstrated him or her to be trustworthy or honorable. Names open doors, if someone receives the recommendation of a respected person. Names are express power, if people shiver when hearing the name of a tyrannical ruler. Names of healers bring hope. Names make people feel at home. All of this holds true for the name of Jesus Christ. Witnessing to the name of Christ as savior does not simply mean the announcement of his lordship. It means letting people feel what Jesus means to us as Christians.

The New Testament itself contains a "name theology." To give some examples: the honor of Jesus Christ is expressed in his name. Phil. 2, 9-10: "Therefore God also highly exalted him and gave him the name that is above every name, so that at the name of Jesus every knee should bend, in heaven and on earth and under the earth, and every tongue should confess that Jesus Christ is Lord, to the glory of God the Father." The name of Jesus is not only honorable, but also a powerful critique against the human exercise of power. Rev. 19, 16: "On his robe and on his thigh he has a name inscribed, 'King of kings and Lord of lords'." The name of Jesus brings joy (Lk. 1, 39-45) and hope, since there "is salvation in no one else, for there is no other name under heaven given among mortals by which we must be saved." (Acts 4,12 ) The name of Jesus opens doors. John 16, 24: "Until now you have not asked for anything in my name. Ask and you will receive, so that your joy may be complete." (See 1. John 5, 13)

Christians, therefore, are called to witness the name of Christ in a sensitive manner and out of personal experience. People should, at least, understand upon what the joy and hope of Christians rests. In German contexts, Christians often avoid the name of Christ because it seems easier to talk about ethics or make general statements about a God in heaven. Such an approach, however, succeeds in only veiling the particular Christian point of view and the spiritual experiences of Christian practices. Christian social activities in Germany very often fail to draw a clear connection between action and belief. It is hard to see how a Christian hospital differs from one without any religious allegiance. It is difficult to make Christian 
witness a topic on the agenda of a Christian social organization if the nurses and doctors do not share Christian convictions - even though they might be members of a church. Since belief is only possible in an environment of free choice, the development of workshops on Christian spiritual practice, seminars on Christian worldview and values and so forth, becomes a matter of importance. First of all, the employees need to be approached in a sensitive manner. A reaffirmation of Christian spirituality, ethics and teachings is needed. To focus on the name of Christ means also to focus on the very symbols of the New Testament, on parables or images that serve to make understandable why Christ is seen as the ultimate revelation of God.

\section{Mission and oikumenical solidarity - Witnessing in a globalized World}

To glorify God through Jesus Christ and in the power of the Holy Spirit is not confined to the acts of worship and prayer, even though these are the primary source of missionary empowerment. Christians serve the world in spreading the Good News by trying to embody it. That is, speaking the message needs the accompaniment of Christian deeds, for these demonstrate the trustworthiness of the message. According to 2. Cor. 9, 11-13, this also includes material help:

"You will be enriched in every way for your great generosity, which will produce thanksgiving to God through us; for the rendering of this ministry not only supplies the needs of the saints but also overflows with many thanksgivings to God. Through the testing of this ministry you glorify God by your obedience to the confession of the gospel of Christ and by the generosity of your sharing with them and with all others."

It is important to note that the English translation of verse 12, "the rendering of this ministry," misses the specific meaning of the Greek original text. Paul speaks specifically of the "ministry of this liturgy" (Greek: he diakonia tēs leitourgias tautēs). The German New Testament scholar Erich Gräßer rightly points out that this thanksgiving is not only seen as a diaconic endeavor, but also as a "liturgical activity". (Gräßer 2002, 63) The collection of money as an act of thanksgiving to God, connects the Christians who are giving to those who are receiving helped. The collection itself is an expression of the overflowing grace Christians have experienced. They are free to give something back because they themselves have received so much from God. On the other hand, the receiving Christians are liberated to praise God for the faith of their sisters and brothers. In this way, both groups are united in the praise of God, even though they are far apart from one another. In the same way, global Christian solidarity with other people and with other Christians is not merely as an expression of Christian 
diaconic responsibility. While important, this singular focus ignores the core issue, that is, the glorification of God through the deeds of Christians and the answers of people.

Christian solidarity can be understood as an expansion of the community of people who are praising God. This is appealing and attracts people from other religious backgrounds. I remember a Muslim woman who became Christian by observing Christians campaigning against female circumcision in the south of Ethiopia. She became Christian, not because of missionary preaching, but by witnessing how Christians fought for young Ethiopian girls, even while they were themselves threatened by the local elders of the community, which was almost entirely Muslim. It was this selfless act that convinced her, and she began asking why these Christians acted the way they did. These 'diaconic' activities prompt a questioning of worldview and religious commitment. For me, this is a convincing example of the glorification of God through deeds that - in the long run - leads to the glorification of God in the name of Jesus Christ. Once again: a doxological understanding of mission needs to remain focused on the glorification of God, but through the freedom of a broad variety of forms.

\section{Mission and prophetic doxology - Witnessing in the midst of power struggles}

Mission as oikumenical doxology should not be misinterpreted as being apolitical. The opposite holds true. According to the Gospel of Luke, Mary magnifies God as the "Mighty One" who "has done great things for me, and holy is his name." (Lk. 2:49) The praise of God describes the deeds of God who "scattered the proud" and "lifted up the lowly" (2: 51-52). It is precisely God the "mighty" (Greek: dynatos) who "brought down the powerful [Greek: dynastas] from their thrones" (Lk. 2:52). (Berges / Hoppe 2009, 81) In other words, the liturgical praise of Mary magnifies God as the ultimate power in the world. In comparison to this power all worldly powers are revealed to be illusions. Jesus Christ, as the "Son of the Most High" (Lk. 1:32) and as "mighty savior" (Lk. 1:69), has been waited for and born within a world of conflict, as is clearly expressed in the doxological praise of Mary (Lk. 1:46-55) and the praise of Zechariah (Lk. 2: 68-79). These praises are equally prophetic critiques: the power of God the mighty who sends his Son to spread the Good News, to expand the Kingdom of God and to confront the sin of humankind, challenges all earthly powers and structures. Only doxological praise can express this truth since doxology is the ultimate realization of the content of the words been used: in praising God as the ultimate power in heaven and on earth, the bringer of justice for the oppressed and downtrodden, and peace and abundant life to all human beings, this power already at work among the praising community. The act of praise itself challenges the earthly powers of unjust rulers, corrupt elites and oppressive regimes. (Wrogemann 2013, 400-440) 
The announced "Son of the Most High" is born through Mary as a human being, but originated through the Holy Spirit. The angel announces that "the Holy Spirit will come upon you, and the power of the Most High will overshadow you; therefore the child to be born will be holy; he will be called Son of God" (Lk. 1:35). This precedes the mission of Jesus Christ as the carrier of the Holy Spirit, as expressed in Lk. 4: 18-19: "The Spirit of the Lord is upon me, because he has anointed me to bring good news to the poor. He has sent me to proclaim release for the captives and recovery of sight to the blind, to let the oppressed go free, to proclaim the year of the Lord's favor." These links clearly show that doxological praise is one important dimension of Christian mission. It expresses the encompassing importance of the mission of Jesus Christ on a personal, social, cultural and political and even ecological level.

Mission as oikumenical doxology is an important dimension of the resistance by Christians in Africa, Asia and Latin America to oppression and discrimination. Liberation theologians soon realized that no struggle for justice or better living conditions would be possible without a spirituality of resistance. This enables people to survive long periods of oppression. It time and again helps raise the self-esteem of people broken be oppressive cultural ideologies.

But a doxological understanding of Christian mission is also needed in European contexts, where, after a long period of decline, Christians need to overcome an atmosphere of depression and despair concerning the future of the church. A large number of Christians in European countries think that mission either should not occur or is simply no longer possible. This attitude seems to be an outcome of a rather depressive atmosphere. Under these circumstances, a fresh approach is needed, one that glorifies God as the one who conducts his mission by himself and who brings forth fruit for harvest whenever and wherever he wants. This approach would free Christians from thinking that the survival of the churches depends on them. This is spiritually speaking - not the case. Such thinking is an expression of human hubris. Only if Christians focus anew on the spiritual basis of their Christian identity they will be able to fulfill their mission, and that is in the first place, to glorify God through praise and prayer, through the life-expression of Christian communities and Christian involvement in the world. Not only should unjust political and economic structures be challenged, but also social atmospheres of indifference regarding religion, atmospheres of consumerism and materialism, and social developments of individualism and privatization, and all of this in societies within a situation of decline of Christian churches and congregations. 


\section{Christian Churches in European societies - Challenges and Prospects}

European churches are challenged in many ways. Simple missiological answers will not help. No quick solution will reverse Christianity's rate of decline in European countries; this is a task of decades. Mission needs to be grounded on a firm theological basis, because Christian churches, congregations and single believers will have to stand these challenges for a long time. A doxological approach helps to carry the burden. It helps distance oneself from a false hubris which makes one responsible for the survival of the church, and from a false frustration which thinks of God as powerless to change the situation. Out of a doxological perspective, God has promised to stay with his witnesses through all hardships and to sustain them with the power of the Holy Spirit in the name of Jesus Christ to witness to the gospel, and to the Kingdom of God to come. This promise is the cornerstone for the future of the European churches and the beginning of a new phase of revitalization.

\section{Bibliography}

Berger, P. L. (1963): A Market Model for the Analysis of Ecumenicity, in: Social Research (30), 77-93.

Berges, U.; Hoppe, R. (2009): Arm und Reich, Würzburg, 81.

Bevans, S.; Schroeder, R. (2004): Constants in Context, Maryknoll / New York.

Blum, M. (2008): > Gib uns, dass wir sitzen ... in deiner Herrlichkeit $<$. Doxa bei den Synoptikern, in: R. Kampling (Hg.), Herrlichkeit, Paderborn u.a., 57-78.

Finke, R.; Stark, R. (2005): The Churching of America, 1776-2005: Winners and Loosers in Our Religious Economy, Rutgers University Press.

Gabriel, K.; Gärtner, C.; Pollack, D. (Hg.) (2012): Umstrittene Säkularisierung. Soziologische und historische Analysen von Religion und Politik, Berlin

Gräßer, E. (2002): Der zweite Brief an die Korinther, Band 2, Gütersloh, 63.

Harrison, J. R. (2010): The Brothers of the $>$ Glory of Christ $<$ (2 Cor 8:23). Paul's Doxa Terminology in Its Ancient Benefaction Context, in: Novum Testamentum (52), 156-188.

Hopkins, B. (21992): Church Planting. Models for Mission in the Church of England, Nottingham. 
Nielsen, J. T. (2010). The Narrative Structures of Glory and Glorification in the Fourth Gospel, in: NTS (56), 343-366.

Pickel, G. (2009): Revitalization of Religion as Normalization? - Romania in Comparative European Perspective, in: Studia Sociologica (54/2), 9-36.

Pickel, G. (2009a): Secularization as a European Fate? Results from the Church and Religion in an enlarged Europe Project 2006, in: Pickel / Müller (Hg.), 89-122.

Pickel, G.; Müller, O. (Hg.) (2009): Church and Religion in Contemporary Europe. Results from Empirical and Comparative Research, Wiesbaden.

Pickel, G.; Müller, O. (Hg.) (2009): Church and Religion in Contemporary Europe. Results from Empirical and Comparative Research, Wiesbaden.

Pollack, D.; Müller, O. (2011): Die religiösen Entwicklungen in Ostdeutschland nach 1989, in: G. Pickel; K. Sammet (Hg.), Religion und Religiosität im vereinten Deutschland, Wiesbaden, 125-144, 127.

Pollack, D.; Pickel, G. (2007): Religious Individualization or Secularization? Testing hypotheses of religious change - the case of Eastern and Western Germany, in: British Journal of Sociology (58/4), 603-632.

Stark, R.; Finke, R. (2002): Beyond Church and Sect: Dynamic and Stability in Religious Economies, in: T.G. Jelen (Hg.), Sacred Markets, Sacred Canopies: Essays on Religious Markets and Religious Pluralism, Lanham: Rowman and Littlefield Publishers, 31-62, 32-33.

Stark, R.; Iannaccone, L. R. (1994): A supply-sided Reinterpretation of the $>$ Secularization $<$ of Europe, in: Journal for the Scientific Study of Religion (33), 230-252.

Wrogemann, H. (2012): Den Glanz widerspiegeln. Über den Sinn der christlichen Mission, ihre Kraftquellen und Ausdrucksgestalten. Interkulturelle Impulse für deutsche Kontexte, 2. erweiterte Auflage, Münster. (To Mirror the Splendor: the Meaning of Christian Mission, its Sources of power and Forms. Intercultural Impulses for German contexts, first edition 2009).

Wrogemann, H. (2012a): Interkulturelle Theologie und Hermeneutik. Grundfragen, aktuelle Beispiele, theoretische Perspektiven (Intercultural Theology and Hermeneutics. a textbook for Intercultural Theology / Missiology, Volume 1), Gütersloh. 
Wrogemann, H. (2013): Missionstheologien der Gegenwart. Globale Entwicklungen, kontextuelle Profile und ökumenische Herausforderungen, Lehrbuch Interkulturelle Theologie / Missionswissenschaft, Band 2, Gütersloh, 400-440. (Contemporary Mission Theologies. Global developments, contextual profiles, ecumenical challenges, a textbook for Intercultural Theology / Missiology, Volume 2) 